\title{
The Influence of Transformational and Transactional Leadership on Organizational Performance in Millennials Generation
}

\author{
Syarifa Hanoum ${ }^{1 *}$, Muniroh ${ }^{1}$, Agung Nabawi $\mathrm{S}^{1}$ \\ ${ }^{1}$ Business Management, Institut Teknologi Sepuluh Nopember Surabaya, Surabaya, 60111, Indonesia \\ ${ }^{*}$ Corresponding author.Email: syarifa@mb.its.ac.id
}

\begin{abstract}
Indonesia's population has filled by millennial generation. This millennial generation has a labor force participation contribution of $67.24 \%$ by its total population. It is estimated that research to develop the millennial generation while the leadership style is still rarely found in members of the millennial generation. This study aims to find out transformational and transactional leadership on organizational performance in millennial generation from oil and gas industry because its volatility in a last decade. The research variables used in this study are transformational, transactional leadership, and mediation variables used to link previousvariables are knowledge sharing, organizational learning, and job performance that links previous variables to affect organizational performance. The model test is using Structural Equation Modeling (SEM) to test theresearch model and hypothesis. This study used a questionnaire distributed online and obtained 150 respondents from all parts of the company. The result is transformational leadership that influences organizational performance through organizational learning mediating variables. Transformational and transactional leadership positively influences knowledge sharing variables. Organizational performance is also needed by organizational learning and job performance.
\end{abstract}

Keywords: Organizational Performance, Transformational Leadership, Transactional Leadership, StructuralEquation Model.

\section{INTRODUCTION}

Millennial generation in Indonesia has a labor force participation of $67.24 \%$. In preparing millennial generation into a workforce that can escalate the performance of domestic organizations, studies are needed to study the characteristics of millennial generation. Millennial generation illustrates a lack of loyalty and workethic [1]. Millennial generation is also supported to support contributions at the workplace level and to reconcile work [2]. On the other hand, they also have lower endurance than the previous generation [2]. These characteristics will affect their work environment. However, phenomena related to millennial characteristics in the work environment that are still minimally investigated are related to leadership styles that intersect with their characteristics.

Leadership style can be said as the ability to motivate and influence subordinates collectively so that they can contribute to the achievement of the goals given by the team and organization [3]. There is research that states that leadership styles in an organization with transformational leadership and transactional leadership [4]. This phenomenon has been presented in previous studies involving transformational and transactional leadership styles that influence employee knowledge sharing practices, and the latest changes in performance, and then on company performance [5]. These studies 
suggest a relationship between leadership style and organizational performance.

In line with these findings, the study of leadershipin the loose oil and gas industry states that leadership in work operations and communication is an important activity in the oil and gas industry [6]. An additional effect of leadership involvement emphasizedin the loose oil and gas industry is that it allows good interpersonal relationships with subordinates, relationships that are characterized by trust, openness, and honesty [6]. This gap can produce research for development in the millennial generation and produce a workforce that is able to escalate the performance of an organization.

Therefore, the industry used in this study is the oiland gas industry in Indonesia. The oil and gas industry in Indonesia which is experiencing volatility in oil barrel production in 2004 was able to produce above 1 million barrels / day to 800 thousand barrels / day in 2018 [7]. State revenue from the oil and gas industry fell $80 \%$ from Rp 216 trillion in 2014 (14\% of state revenue) to $\mathrm{Rp} 44$ trillion in 2016 (2.8\% of state revenue) [7].

\section{THEORETICAL BASIS}

\subsection{Transformational Leadership}

Transformational leadership is defined as the process of leaders in inspiring their followers to perform ata higher level than expected and potentially exceeding the followers' own interests to a high level of shared vision [4]. As a result, followers in conditions of transformational leadership can maximize the performance of their subordinates and increase the level of feeling of motivation, organizational commitment, satisfaction, trust and work involvement [8]. In addition, these leaders demonstrate persistence and determination in pursuing goals, demonstrate high standards of ethical principles and moral behavior, sacrifice themselves for the benefit of others, consider the needs of subordinates above their own needs, and share success and risk with subordinates [9]. The usual treatment by transformational leaders will be embedded in their subordinates well, so that the leader can increase employee involvement in an organization.

\subsection{Transactional Leadership}

Transactional leadership is built on the premise of a reciprocal relationship between leaders and their subordinates [10]. In transactional leadership, leaders pursue the exchange of costs and benefits with followers because of their material and psychological needs to achieve the expected performance [11]. Here, the leader clarifies to the follower what needs to be done to get rewarded for efforts through directives and participation in accordance with the leader's direction [12].

\subsection{Knowledge Sharing}

Knowledge is the most important aspect for the organization and knowledge management activities have become an integral and important aspect of corporate strategy [13]; [14]. Knowledge sharing, one of the knowledge management processes, which is considered first generation knowledge management and must be made visible in organizations by making part of their business strategy, initiating to the main business, routinely, matching the organization's style, and aligning rewards [15]. Knowledge sharing occurs when someone wants to be involved in the collection of knowledge and contribute knowledge to new ideas that increase [16]. The outcome of knowledge sharing depends on the quality and quantity of communication between human resources, readiness to use individual knowledge and competence [17].

\subsection{Organizational Learning}

Organizational learning is a set of actions in an organization that intentionally and unintentionally influences positive organizational change [18]. Organizational learning can be used as an organization's ability to survive and remain competitive in an economic volatility and uncertainty in the era of globalization. Organizational learning can be seen as a dynamic process based on knowledge, which implies moving between various levels of action, going from individual to group level, and then to organizational level [19]. At present, organizational learning is explained at the level of strategic management and is made an organization as a source of competitive advantage.

\subsection{Job Performance}

Job performance is related to the level of productivity of behavior related to individual work [20]. Job performance can be measured using several methods such as quality of work, timeliness, performance, productivity, training effectiveness, assessment, work results, behavior, and personal characteristics [21].

\subsection{Organizational Performance}

Organizational performance is the organization's competence to change resources within the company efficiently and effectively to achieve organizational goals [22]. There are four factors to measure organizational performance namely, HR results, organizational results, services, financial accounting results, and capital market results [23].It can be assumed that the objective of strategic human resource management is to have an impact on organizational performance through increasing the probability of achieving goals. 


\subsection{Millennial Generation}

The millennial generation used in this study is the labor force born around 1980-1999 [24].

\subsection{Research Objectives}

This study aims to determine the effect of transformational leadership and transactional leadership that influence the knowledge sharing and organizational learning that drives the work performance of employees with the final impact on organizational performance distributed to millennial generation employees in one of Indonesia's oil and gas companies.

\section{METHOD}

\subsection{Sample and Data Collection Procedures}

The sample for this study were 150 employees at one of Indonesia's oil and gas companies. Research respondents have the criteria that they are millennial generation employees with birth years from 1980 to 1999. This study was filled by employees of several work units in the company and the majority of them came from production work units which were divided into 3 parts, namely: Production I with 11 respondents, Production II with 54 respondents, Production III with 42 respondents with total respondents from Production $71 \%$ of the total respondents of this study. Respondents have diverse backgrounds, namely at the high school education level of 55 respondents, diploma education level of 53 respondents, and scholars as many as 39 respondents. The respondents have work experience in companies for 4-6 years as much as $35 \%$ of the total population of respondents. A total of $61 \%$ of the total respondents had born in 1990-1999.

The sampling method used in this study is nonprobability sampling aimed at completing the type of case study research and in-depth study of the sample is needed so that it can provide an appropriate perspective in analyzing research questions. The researcher distributes a questionnaire containing a Likert scale statement that is distributed and collected online to companies that are subject to research. The Likert scale used is, 1 "strongly disagree", 2 "disagree", 3 "sufficient", 4"agree", 5 "strongly agree".
The variables in this study contain 6 latent variables with 35 indicators that can represent the latent variables in the research questionnaire. The independent variable used in this study consisted of transformational leadership (TF) and transactional leadership (TC) adopted from the study of Dai. Other variables such as knowledge sharing (KS) from Vuori and Okkonen, organizational learning (OL) from Garcia-Morales [25], Job performance (JP) was adapted from Tseng and Huang [21] and organizational performance (OP) was adapted from the research of Chen and Choi [26]. Therefore, this study used structural equation modeling method.

\subsection{Measures}

Every indicator used in the research questionnaire will be measured using factor loading to find out that each indicator represents its latent variable based on the statement that has been filled in by the respondent. Latent variables will be measured for validity through construct reliability and average variance extracted in order to provide a value that measures the reliability of research variables on each variable. The cut-off value used in factor loadings is 0.7 [27], [28], construct reliability is 0.6 , and average variance extracted is 0.5 [29]; [30]. Furthermore, the variables in this study will be measured by Cronbach's alpha with a cut-off value of 0.7 .

In this measurement there are several indicators that do not meet the cut-off value of factor loadings so that they will be reduced because in the structural equation modeling the addition or subtraction of an indicator can affect the wholemodel. After reducing several indicators and recalculating to find out whether each variable meets the cut-off value of each indicator that measures its validity. It was found that all variables had met the minimum value set both in factor loadings, construct reliability, and extracted average variance. Therefore, the conclusion of this validity measures states that the data used have a good level of accuracy. However, in this study all variables have passed the cut-off value of cronbach's alpha. 
Table 1. FL, CR, and AVE on Each Variable

Cronbach's $\quad C R \quad A V E$

Alpha

\begin{tabular}{cccc} 
& $>0.7$ & $>0.6$ & $>0.5$ \\
\hline $\mathrm{TF}$ & 0.914 & 0.92 & 0.61 \\
\hline $\mathrm{TC}$ & 0.815 & 0.82 & 0.69 \\
\hline $\mathrm{KS}$ & 0.894 & 0.88 & 0.65 \\
$\overline{\mathrm{OL}}$ & 0.887 & 0.89 & 0.72 \\
$\mathrm{JP}$ & 0.95 & 0.95 & 0.76 \\
\hline $\mathrm{OP}$ & 0.929 & 0.93 & 0.77 \\
\hline
\end{tabular}

Note: the construct used in this table is reduced from the measurement of factor loadings.

\section{RESULT}

This section will present statistical requirements on the data used, test model fit research, and test hypothesis research. In the statistical requirements, no outliers were found from the 150 data in this study and the data were normally distributed through the Q-Q plot as a normality test analysis tool. Variables also have a linear relationship because they form certain patterns in the scatter plot diagram. In the multicollinearity test, the indicator used is atolerance value $>0.1$ or VIF $<10$. And these variables already meet the cut-off value of the indicator used by using the organizational performance (OP) as the dependent variable.

Table 2. Multicollinearity Statistics

\begin{tabular}{|c|c|c|}
\hline \multirow{2}{*}{\multicolumn{2}{|c|}{$\frac{\text { Statistics }}{\text { Variable }}$}} & \multirow{3}{*}{$\underline{\text { VIF }}$} \\
\hline & & \\
\hline \multicolumn{2}{|c|}{ Tolerance } & \\
\hline $\mathrm{TF}$ & 0.402 & 2.49 \\
\hline $\mathrm{TC}$ & 0.613 & 1.63 \\
\hline $\mathrm{KS}$ & 0.363 & 2.75 \\
\hline $\mathrm{OL}$ & 0.447 & 2.23 \\
\hline $\mathrm{JP}$ & 0.694 & 1.44 \\
\hline
\end{tabular}

This study uses three main measurements in the model-fit test, namely absolute fit indices, incremental fit indices, and parsimony fit indices, each of which has its own benchmarks on each measurement. After being tested using AMOS 22 software, this research model fulfills all the requirements values so that it can be said that the model is fit. 
Table 3. Model-Fit (Measurement fit Indices)

Default Model

\begin{tabular}{lll}
\hline & Cut-off & Value \\
& Value & \\
\hline & & \\
\hline RMR & $\leq 0,1$ & 0.099 \\
RMSE & $<0,1$ & 0.094 \\
A & & \\
NFI & $\geq 0,8$ & 0.816 \\
TLI & $\geq 0,8$ & 0.872 \\
CFI & $\geq 0,8$ & 0.885 \\
PNFI & $0,60-0,90$ & 0.731 \\
PGFI & $\underline{0,50-1,00}$ & $\underline{0.621}$ \\
\hline
\end{tabular}

Furthermore, the hypotheses in this study have as many as 8 hypotheses. The effect of transformational leadership (TF) on knowledge sharing (KS). The influence of transactional leadership (TC) on knowledge sharing (KS). The effect of transformational leadership (TF) on organizational learning (OL). The effect of transformational leadership (TF) on job performance
(JP). Effect of transactional leadership (TC) on job performance (JP). The effect of knowledge sharing (KS) on job performance (JP). The effect of organizational learning (OL) on organizational performance (OP). Effect of job performance (JP) on organizational performance (OP).

Figure 1. Research Model

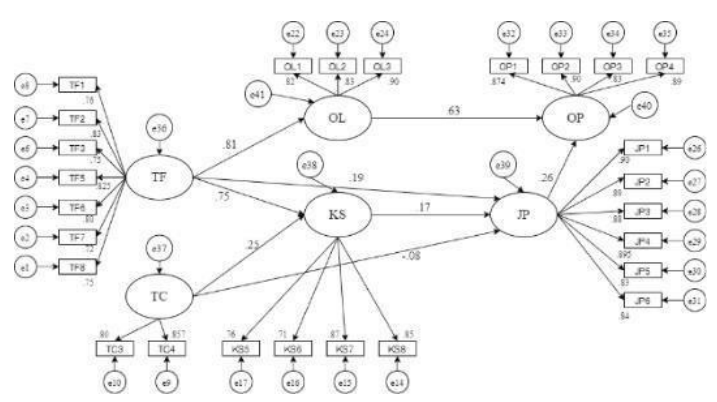

Furthermore, the hypothesis test was performed on AMOS 22 software by looking at the p-value of the relationship between variables with a p-value significance value of $<0.05$ from the relationship between variables. A p-value less than 0.05 will illustrate that the research hypothesis is accepted, but if it is greater than 0.05 will be rejected. The value of a positive or negative relationship can be known from the value of the standardized coefficient ( $\beta$ ), if the value of $\beta$ is positive it will show a positive relationship between the variables tested, and vice versa. 
Table 4. Summary of proposed results for the researchmodel

\begin{tabular}{|c|c|c|c|c|c|}
\hline & \multicolumn{2}{|c|}{ Hypothesis } & \multirow{2}{*}{$\begin{array}{c}(\beta) \\
0.75\end{array}$} & \multirow{2}{*}{$\begin{array}{c}\begin{array}{c}\mathrm{P}- \\
\text { Value }\end{array} \\
0.002\end{array}$} & \multirow[b]{2}{*}{ Supported } \\
\hline \multirow[b]{2}{*}{1} & $\mathrm{H}$ & $\mathrm{TF} \rightarrow \mathrm{K}$ & & & \\
\hline & S & & 2 & & \\
\hline \multirow[b]{2}{*}{2} & $\mathrm{H}$ & $\mathrm{TC} \rightarrow \mathrm{K}$ & 0.24 & 0.009 & Supported \\
\hline & $\mathrm{S}$ & & 9 & & \\
\hline \multirow{3}{*}{3} & $\mathrm{H}$ & $\mathrm{TF} \rightarrow \mathrm{O}$ & 0.81 & 0.002 & Supported \\
\hline & $\mathrm{L}$ & & 5 & & \\
\hline & & & & & Not \\
\hline \multirow[t]{2}{*}{4} & $\mathrm{H}$ & $\mathrm{TF} \rightarrow \mathrm{JP}$ & $\begin{array}{l}0.19 \\
4\end{array}$ & 0.297 & \\
\hline & & & & & Supported \\
\hline \multirow{3}{*}{5} & & & - & & Not \\
\hline & $\mathrm{H}$ & $\mathrm{TC} \rightarrow \mathrm{JP}$ & & 0.345 & \\
\hline & & & $\begin{array}{l}0.08 \\
1\end{array}$ & & Supported \\
\hline \multirow{3}{*}{6} & & & & & Not \\
\hline & $\mathrm{H}$ & $\mathrm{KS} \rightarrow \mathrm{JP}$ & $\begin{array}{l}0.17 \\
4\end{array}$ & 0.447 & \\
\hline & & & & & Supported \\
\hline \multirow{3}{*}{7} & $\mathrm{H}$ & $\mathrm{OL} \rightarrow \mathrm{O}$ & 0.63 & 0.002 & Supported \\
\hline & $\mathrm{P}$ & & 2 & & \\
\hline & $\mathrm{H}$ & $\mathrm{JP} \rightarrow \mathrm{OP}$ & 0.25 & 0.002 & Supported \\
\hline 8 & & & 6 & & \\
\hline
\end{tabular}

Based on the above table, researchers get 5 hypotheses received from 8 hypotheses, namely $\mathrm{H} 1, \mathrm{H} 2$, $\mathrm{H} 3, \mathrm{H} 7, \mathrm{H} 8$. Unacceptable hypotheses occur in the scope of job performance (JP) as the dependent variable. $\mathrm{H} 1, \mathrm{H} 3$, and $\mathrm{H} 7$ have greater $\beta$ values than other hypotheses whichindicate that it has a greater influence on the dependent variable than other hypotheses.

\section{DISCUSSION}

After analyzing each hypothesis, the researcher provides managerial implications for the company. In the $\mathrm{H} 1$ and $\mathrm{H} 3$ hypotheses related to transformational leadership, companies can provide training around transformational leadership and assign responsibilities to each boss to always motivate millennial generation employees in the work environment and make sharing sessions to implement transformational leadership styles in organizations. In addition to training, the company can also give responsibilities to superiors to create a climate that suits the preferences of millennial employees as a learning tool. The company can provide training to superiors with the following aspects: transparency of rewards due to the implementation of duties, employee supervision, and incentive / reward calculation systems.

In the $\mathrm{H} 7$ and $\mathrm{H} 8$ hypotheses, the authors provide managerial implications to the company to create a new learning system that is critical of the condition of the oil and gas industry and organizational management knowledge in general and oversees the achievement of individual employee job performance. Both aspects will influence the achievement of organizational performance specifically in millennial generation employees as a driving force in the company.

\subsection{Limitations and Future Research}

The limitations of this study are found in the uneven distribution of online questionnaires in each work unit of the company. In addition, the limitations of this study at the age of respondents make this study relevant for employees with millennial generation criteria.

\subsection{Conclusions}

The results of this study prove that transformational and transactional leadership have a significant and positive effect on the knowledge sharing variable of millennial generation employees in Indonesian oil and gas companies. Transformational leadership has a significant and positive influence on organizational 
learning for millennial generation employees in Indonesian oil and gas companies. Transformational and transactional leadership, and knowledge sharing do not have a significant effect on job performance for millennial generation employees in Indonesian oil and gas companies. Organizational learning and job performance have a significant and positive influence on organizational performance according to millennial generation employees in Indonesian oil and gas companies.

\section{REFERENCES}

[1] C. Marston, Myths about Millennials: Understand the myths to retain Millennials. 2009.

[2] S. Y. Chou, "Millennials in the Workplace: A Conceptual Analysis of Millennials' Leadership and Followership Styles," Int. J. Hum. Resour. Stud., vol. 2, no. 2, 2012, doi: 10.5296/ijhrs.v2i2.1568.

[3] P. Hersey and K. H. Blanchard, Psicologia para administradores: a teoria $e$ as técnicas da liderança situacional. 1986.

[4] B. M. Bass, "Two Decades of Research and Development in Transformational Leadership," Eur. J. Work Organ. Psychol., vol. 8, no. 1, pp. 932, 1999, doi: 10.1080/135943299398410.

[5] R. Masa'deh, B. Y. Obeidat, and A. Tarhini, “A Jordanian empirical study of the associations among transformational leadership, transactional leadership, knowledge sharing, job performance, and firm performance: A structural equation modelling approach," J. Manag. Dev., vol. 35, no. 5, pp. 681-705, 2016, doi: 10.1108/JMD-092015-0134.

[6] A. O'Dea and R. Flin, "Site Managers and Safety Leadership in The Offshore Oil and Gas Industry," Saf. Sci., vol. 37, no. 1, pp. 39-57, 2001.

[7] PwC, J. C. Roca, C. M. Chiu, and F. J. Martínez, "Oil and Gas in Indonesia. Taxation Guide," Int. J. Hum. Comput. Stud., vol. 64, no. 8, pp. 683696, 2016, doi: 10.1016/j.ijhcs.2006.01.003.

[8] P. M. Podsakoff, S. B. MacKenzie, and W. H. Bommer, "Transformational leader behaviors and substitutes for leadership as determinants of employee satisfaction, commitment, trust, and organizational citize," J. Manag., vol. 22, no. 2, pp. 259-298, 1996, doi: 10.1016/S01492063(96)90049-5.

[9] K. Limsila and S. O. Ogunlana, "Performance and leadership outcome correlates of leadership styles and subordinate commitment," Eng. Constr. Archit. Manag., vol. 15, no. 2, pp. 164-184, 2008, doi: 10.1108/09699980810852682.
[10] G. F. Vito, G. F. Vito, and G. E. Higgins, "Transactional and transformational leadership: An examination of the leadership challenge model," Policing, vol. 37, no. 4, pp. 809-822, 2014, doi: 10.1108/PIJPSM-01-2014-0008.

[11] J. C. Sarros and J. C. Santora, "The transformational- transactional leadership model in practice," Leadersh. Organ. Dev. J., vol. 22, no. $8, \quad$ pp. 383-394, 2001, doi: 10.1108/01437730110410107.

[12] H. Erkutlu, "The impact of transformational leadership on organizational and leadership effectiveness: The Turkish case," J. Manag. Dev., vol. 27, no. 7, pp. 708-726, 2008, doi: 10.1108/02621710810883616.

[13] G. S. Iyer and S. Ravindran, "Usefulness, incentives and knowledge management," $J$. Knowl. Manag., vol. 13, no. 6, pp. 410-430, 2009, doi: 10.1108/13673270910997097.

[14] R. O. Shannak, R. M. d T. Masa'deh, Z. M. F. AlZu'bi, B. Y. Obeidat, M. Alshurideh, and H. Altamony, "A theoretical perspective on the relationship between knowledge management systems, customer knowledge management, and firm competitive advantage," Eur. J. Soc. Sci., vol. 32, no. 4, pp. 520-532, 2012.

[15] C. Vorakulpipat and Y. Rezgui, "An evolutionary and interpretive perspective to knowledge management," J. Knowl. Manag., vol. 12, no. 3, pp. 17-34, 2008, doi: 10.1108/13673270810875831.

[16] G. W. Bock and Y. G. Kim, "Breaking the myths of rewards: An exploratory study of attitudes about knowledge sharing," Inf. Resour. Manag. J. IRMJ, vol. 15, no. 2, pp. 14-21, 2002.

[17] L. F. Liao, "A learning organization perspective on knowledge-sharing behavior and firm innovation," Hum. Syst. Manag., vol. 25, no. 4, pp. 227-236, 2006.

[18] G. F. Templeton, B. R. Lewis, and C. A. Snyder, "Development of a measure for the organizational learning construct," J. Manag. Inf. Syst., vol. 19, no. 2, pp. 175-218 $10 \quad 1080 \quad 07421222 \quad 2002$ 110457 27, 2002.

[19] M. M. Crossan, H. W. Lane, and R. E. White, “An organizational learning framework: From intuition to institution," Acad. Manage. Rev., vol. 24, no. 3, pp. 522-537, 1999.

[20] Z. Shooshtarian, F. Ameli, and M. Amini Lari, "The Effect of Labor's Emotional Intelligence on Their Job Satisfaction, Job Performance and Commitment Keywords: In 1997, Mayer and Salovey described four abilities that contribute to emotional Intelligence: 1. Perception: It involves accurate ver," Iran. J. Manag. Stud., vol. 6, no. 1, pp. 27-43, 2013, doi: 10.5539/ijbm.v11n2p69. 
[21] S. M. Tseng and J. S. Huang, "The correlation between Wikipedia and knowledge sharing on job performance," Expert Syst. Appl., vol. 38, no. 5, pp. 6118-6124, 2011, doi: 10.1016/j.eswa.2010.11.009.

[22] R. L. Daft, S.-W. Cengage, Y. D. Ohio Dai, Y. Y. Dai, K. Y. Chen, and H. C. Wu, Organizational Theory and Design, Sixth. 1997.

[23] L. Dyer and T. Reeves, Human resource strategies. 1995.

[24] J. M. Twenge and S. M. Campbell, "Who are the Millennials? Empirical evidence for generational differences in work values, attitudes and personality," in Managing the new workforce: International perspectives on the millennial generation, 2012, pp. 152-180.

[25] V. J. García-Morales, F. J. Lloréns-Montes, and A. J. Verdú- Jover, "The effects of transformational leadership on organizational performance through knowledge and innovation," Br. J. Manag., vol. 19, no. 4, pp. 299-319, 2008, doi: $10.1111 / \mathrm{j} .1467-8551.2007 .00547 . x$.
[26] P. J. Chen and Y. Choi, "Generational differences in work values: A study of hospitality management," Int. J. Contemp. Hosp. Manag., vol. 20, no. 6, pp. 595-615, 2008, doi: 10.1108/09596110810892182.

[27] C. S. Lin, S. Wu, and R. J. Tsai, "Integrating perceived playfulness into expectationconfirmation model for web portal context," Inf. Manage., vol. 42, no. 5, pp. 683-693, 2005, doi: 10.1016/j.im.2004.04.003.

[28] C. Fornell and D. F. Larcker, "Evaluating Structural Equation Models with Unobservable Variables and Measurement Error," J. Mark. Res., vol. 18, no. 1, p. 39, 1981, doi: 10.2307/3151312.

[29] J. H. Wu and S. C. Wang, "What drives mobile commerce? An empirical evaluation of the revised technology acceptance model," Inf. Manage., vol. 42, no. 5, pp. 719-729, 2005, doi: 10.1016/j.im.2004.07.001.

[30] J. H. Wu, Y. C. Chen, and L. M. Lin, "Empirical evaluation of the revised end user computing acceptance model," Comput. In, 2007. 